\title{
ZRÓŻNICOWANIE ŁĄCZNEJ PRODUKTYWNOŚCI CZYNNIKÓW PRODUKCJI W POWIATACH WOJEWÓDZTWA PODKARPACKIEGO
}

\begin{abstract}
Artykuł przedstawia zróżnicowanie łącznej produktywności czynników produkcji w powiatach województwa podkarpackiego. Celem artykułu jest oszacowanie łącznej produktywności czynników produkcji. Ponadto $\mathrm{w}$ artykule przedstawiono przestrzenne zróżnicowanie poziomu jak i dynamiki omawianej zmiennej. Okres analiz obejmował lata 2003-2014. W celu wyznaczenia łącznej produktywności czynników produkcji, autor dokonał dezagregacji PKB z poziomu wojewódzkiego na poziom powiatowy. Natomiast łączną produktywność czynników produkcji wyliczono opierając się o uprzednio zdezagregowaną wartość PKB na poziomie powiatowym oraz o neoklasyczną, potęgową, funkcję produkcji typu Cobba-Douglasa. Parametry funkcji produkcji zostały oszacowane w oparciu o uogólnioną metodę momentów (generalized method of moments). $\mathrm{Z}$ przeprowadzonych $\mathrm{w}$ artykule rozważań możemy wyciągnąć następujące wnioski. Najwyższe wartości zdezagregowanego PKB per capita notowane były w powiatach Rzeszowie, mieleckim, bieszczadzkim, stalowowolskim oraz tarnobrzeskim. Najniższe, jak na warunki województwa podkarpackiego, wartości zdezagregowanego PKB na mieszkańca występowały w powiatach: przemyskim, lubaczowskim, strzyżowskim, brzozowskim oraz przeworskim. Ponadto najwyższym poziomem łącznej produktywności czynników produkcji, w powiatach województwa podkarpackiego, charakteryzowały się powiaty grodzkie (Rzeszów, Krosno, Tarnobrzeg) oraz powiaty z dobrze rozwiniętym sektorem przemysłowym (stalowowolski, mielecki, dębicki, sanocki). Natomiast w latach 2003-2014 najniższe wartości łącznej produktywności czynników produkcji zostały odnotowane głównie w powiatach południowej oraz południowo-wschodniej części województwa podkarpackiego, do tej grupy powiatów zaliczyć można powiaty: przemyski, strzyżowski, brzozowski, lubaczowski i niżański.
\end{abstract}

Słowa kluczowe: TFP, stopa postępu technicznego, elastyczność wydajności pracy względem technicznego uzbrojenia pracy, przestrzenne zróżnicowanie TFP.

\section{WSTĘP}

Łączna produktywność czynników produkcji (z ang. Total Factor Productivity - TFP) jest miarą, która, obok akumulacji czynników produkcji stanowi istotny czynnik wzrostu gospodarczego. W literaturze przedmiotu można znaleźć badania empiryczne związane

\footnotetext{
${ }^{1}$ Mgr Monika Bolińska, Katedra Ekonomii Matematycznej, Wydział Zarządzania i Komunikacji Społecznej, Uniwersytet Jagielloński, ul. Prof. Stanisława Łojasiewicza 4, 30-348 Kraków; e-mail:monika.bolinska@doctoral.uj.edu.pl

Monika Bolińska, MA, Department of Mathematical Economics, Faculty of Management and Social Communication, Jagiellonian University, ul. Professor Stanisława Łojasiewicza 4, 30-348 Kraków; e-mail: monika.bolinska@doctoral.uj.edu.pl
} 
z problematyką wzrostu gospodarczego ${ }^{2}$. Wskazują one, że przeważającym czynnikiem wpływającym na fluktuacje PKB per capita są właśnie różnice w TFP. Łączną produktywność czynników produkcji określa się w literaturze jako tak zwaną wartość rezydualną lub resztą Solowa. TFP w pewnym stopniu jest wyróżnikiem zmiany efektywności procesów produkcyjnych, który z kolei jest determinowany postępem technicznym. Łączną produktywność czynników produkcji jest zatem pewnym miernikiem wpływu postępu technicznego na tempo wzrostu gospodarczego. W opracowaniu przyjęto metodę oszacowania TFP opartą o dwuczynnikową neoklasyczną funkcję produkcji. TFP $\mathrm{w}$ tym przypadku, to czynnik owej funkcji odpowiadający za zasób wiedzy naukowo-technicznej i do jego wyliczenia należy oszacować parametr określający elastyczność produktu względem kapitału rzeczowego ${ }^{3}$.

Powiaty województwa podkarpackiego charakteryzują się znacznym zróżnicowaniem rozwoju ekonomicznego. Najwyżej rozwiniętym powiatem jest Rzeszów, który jako stolica województwa pełni rolę zarówno lokalnego, jak i regionalnego centrum rozwoju. Wysokim poziomem rozwoju ekonomicznego charakteryzują się również pozostałe powiaty grodzkie, które skupiają wokół siebie głównie sektor usług rynkowych, które z kolei począwszy od lat 90. XX wieku pełnią funkcję stymulatora rozwoju ekonomicznego ${ }^{4}$. Względnie wysoki poziom rozwoju charakteryzuje również powiaty dębicki, mielecki oraz stalowowolski, powiaty skupiają wokół siebie sektor przemysłowy, który na tych terenach ma swoje początki w dwudziestoleciu międzywojennym i jest związany z Centralnym Okręgiem Przemysłowym. Najsłabiej rozwinięte są powiaty z południowej części województwa podkarpackiego. W powiatach tych występuje wysokie bezrobocie strukturalne, które ma swoje początki w latach 90. XX wieku i wiąże się przede wszystkim z likwidacją Państwowych Gospodarstw Rolnych ${ }^{5}$.

Celem opracowania jest przedstawienie przestrzennego zróżnicowania oraz dynamiki TFP w powiatach województwa podkarpackiego w latach 2003-2014. Dane statystyczne zaczerpnięto z Banku Danych Lokalnych Głównego Urzędu Statystycznego, ponadto dobór zmiennych oraz okres analiz podyktowany był dostępnością odpowiednich danych statystycznych. Układ opracowania przedstawia się następująco. W części pierwszej artykułu podjęto próbę dezagregacji PKB z poziomu wojewódzkiego na poziom powiatowy. W kolejnej części scharakteryzowano metodologię oszacowania TFP, zaś w następnej części, w oparciu o zdezagregowane PKB, oszacowano TFP i przedstawiono jego przestrzenne zróżnicowanie oraz dynamikę.

${ }^{2}$ W. Easterly, R. Levine, What Have we learned from a decade of empirical research on growth? It's not factor accumulation: stylized facts and growth model, "World Bank Economic Review", 15(2), 2001; E. Helpman, The mystery of economic growth, Harvard University Press, 2008.

3 T. Tokarski, Oszacowanie regionalnych funkcji produkcji, „Wiadomości Statystyczne”, nr 10, 2008, s. 38-53.

${ }^{4}$ M. Bolińska, Wptyw Specjalnych Stref Ekonomicznych na przestrzenne zróżnicowanie stóp bezrobocia rejestrowanego w powiatach województwa pokarpackiego, „Przegląd Nauk Ekonomicznych”, nr 25, 2017, s. 247-256; S. Dykas, M. Szewczyk, Zróżnicowanie rozwoju ekonomicznego powiatów Polski Wschodniej [w:] Zintegrowane podejście do spójności-rola statystyki publicznej, red. A. Piotrowska-Piątek, Miscellanea Oeconomicae, R. 19, nr 4/2015, t. I, s. 37-56.

${ }^{5}$ M. Bolińska, Przestrzenne zróżnicowanie rozwoju ekonomicznego powiatów województwa podkarpackiego, „Przegląd Nauk Ekonomicznych”, nr 25, 2017, s. 235-246; P. Dykas, T. Misiak, Determinanty podstawowych zmiennych rynku pracy $w$ polskich powiatach $w$ latach 2002-2011, ,Gospodarka Narodowa”, 6/2014, s. 57-80. 


\section{DEZAGREGACJA PKB Z POZIOMU WOJEWÓDZTW NA POZIOM POWIATÓW}

W literaturze przedmiotu można spotkać kilka koncepcji dezagregacji PKB regionalnego (wojewódzkiego) na poziom lokalny (powiatowy). Tego typu analizy były prowadzone w pracach Tokarskiego ${ }^{6}$ lub Ciołek, Brodzickiego ${ }^{7}$ czy też Dykasa, Misiaka ${ }^{8}$. Koncepcja Tokarskiego oparta jest ustaleniu jaki jest udział danego powiatu w wojewódzkim PKB opierając się przy tym na równaniach regresji, w których PKB objaśniane jest za pomocą takich zmiennych jak: wartość produkcji sprzedanej przemysłu, wartość brutto środków trwałych i nakładów inwestycyjnych ${ }^{9}$.

W metodzie zaproponowanej przez Ciołek i Brodzickiego autorzy proponują dezagregację opartą o dane dotyczące podatków oraz przeciętnego funduszu płac ${ }^{10}$. W swojej metodzie autorzy zakładają, że PKB po powiatach kształtuje się zgodnie z przestrzennym rozkładem przeciętnego funduszu płac, który w tej koncepcji rozumiany jest jako średnia płaca brutto ważona liczbą pracujących.

Metoda zaprezentowana przez Dykasa i Misiaka stanowi pewną kompilację powyższych dwóch metod. Autorzy rozszerzyli zaproponowaną przez Tokarskiego metodę oszacowania PKB na poziom powiatów przeliczając udziały poszczególnych powiatów również względem płac. Przedstawione metody posiadają pewne mankamenty i uzyskane przy pomocy tych metod wartości PKB są tylko pewnym przybliżeniem owej zmiennej a nie jej rzeczywistą wielkością wynikającą z metod mierzenia PKB stosowanych przez GUS.

W opracowaniu za podstawę przyjęto procedurę zaproponowaną przez Dykasa i Misiaka, metoda ta oparta jest o następującą procedurę:

1. Na podstawie dostępnych danych na poziomie województw oszacowano parametry następujących równań regresji:

$$
\ln y_{i t}=\alpha+\beta \ln x_{i t}
$$

przy czym $y_{i t}$ to PKB w $i$-tym województwie $(i=1,2, \ldots 16) \mathrm{w}$ roku $t(t=2003$, $2004, \ldots .2014$ ), zmienna $x_{i t}$ (to kolejno) wartości produkcji sprzedanej przemysłu brutto, wartość brutto środków trwałych, wartość inwestycji oraz przeciętne płace brutto w województwie $i$ w roku $t$.

6 T. Tokarski, Zróżnicowanie podstawowych zmiennych makroekonomicznych w powiatach [w:] Statystyczna analiza przestrzennego zróżnicowania rozwoju ekonomicznego i społecznego Polski, red. M. Trojak, T. Tokarski, Kraków, 2013, s. 91-138.

7 D. Ciołek, T. Brodzicki, Determinanty całkowitej produktywności polskich powiatów. Wptyw kapitatu terytorialnego, Working Paper 1, Instytut Rozwoju, 2015.

8 P. Dykas, T. Misiak, Przestrzenne zróżnicowanie TFP w grupach powiatów, referat wygłoszony na konferencji naukowej „Wzrost Gospodarczy - Rynek Pracy -Innowacyjność Gospodarki” organizowanej przez Uniwersytet Łódzki, Łódź czerwiec 2017.

9 T. Tokarski, Zróżnicowanie podstawowych zmiennych makroekonomicznych w powiatach...

${ }^{10}$ D. Ciołek, T. Brodzicki, Determinanty produktywności polskich powiatów, „Bank i Kredyt” 47(5), 2016, s. 463-494. 
Owe oszacowania przedstawiają się następująco (w nawiasach podano wartości p-value) ${ }^{11}$ :

- w przypadku produkcji sprzedanej przemysłu:

$$
\ln y_{i t}=\underset{(0,0000)}{2,1812} \underset{(0,0000)}{0,8440 \ln } x_{i t} \quad \text { skor. } R^{2}=0,92
$$

- w przypadku środków trwałych brutto:

$$
\ln y_{i t}=\underset{(0,0000)}{1,2505} \underset{(0,0000)}{0,8947 \ln x_{i t}} \quad \text { skor.. } R^{2}=0,97
$$

- w przypadku inwestycji:

$$
\ln y_{i t}=\underset{(0,0000)}{3,6474+\underset{(0,0000)}{0,8684} \ln x_{i t}} \quad \text { skor. } R^{2}=0,95
$$

- w przypadku płac:

$$
\ln y_{i t}=\underset{(0,0000)}{-17,2680}+\underset{(0,0000)}{3,5507} \ln x_{i t} \quad \text { skor. } R^{2}=0,63
$$

2. Na podstawie powyższych oszacowań wstępnie przeliczono produkcję sprzedaną przemysłu, środków trwałych brutto, inwestycji i płac na poziomie powiatów, wykorzystując dane statystyczne na poziomie powiatów publikowane przez GUS, na PKB na poziomie powiatów.

3. Uzyskane PKB na poziomie powiatów uśredniono średnią geometryczną.

4. W ostatnim etapie dokonano zbilansowania uśrednionego PKB z PKB na poziomie wojewódzkim w ten sposób, że policzono udziały oszacowanych powiatowych PKB w PKB danego województwa, a następnie uzyskane oszacowania udziałów przemnożono przez publikowane przez GUS wielkości wojewódzkiego PKB.

\section{ZRÓŻNICOWANIE PKB W POWIATACH WOJEWÓDZTWA PODKARPACKIEGO}

Województwo podkarpackie charakteryzuje się wysokim wewnętrznym zróżnicowaniem przeciętnej wartości PKB w przeliczeniu na mieszkańca. Mapa 1 przedstawia przestrzenne zróżnicowanie PKB per capita w powiatach wspomnianego województwa w latach 2003-2014. Z mapy tej możemy wyciągnąć następujące wnioski.

- W analizowanym okresie czasu najniższymi wartościami PKB na mieszkańca charakteryzowały się powiaty o charakterze rolniczym tj., przemyski $(38,95$ tys. zł), lubaczowski (44,97 tys. zł), strzyżowski (45,08 tys. zł), brzozowski (58,42 tys. zł) oraz przeworski $(69,17$ tys. zł).

- Niskie wartości analizowanej zmiennej makroekonomicznej zostały odnotowane w powiatach: jarosławskim (69,75 tys. zł), niżańskim (74,28 tys. zł), rzeszowskim (74,91 tys. zł), kolbuszowskim (77,56 tys. zł) i krośnieńskim (82,77 tys. zł).

\footnotetext{
${ }^{11} \mathrm{~W}$ opracowaniu wszystkie równania oszacowane zostały w oparciu o uogólnioną metodę momen-
} tów (generalized method of moments - dalej: GMM). 
- Średni poziom PKB w przeliczeniu na mieszkańca występował w powiatach: łańcuckim (88,61 tys. zł), jasielskim (88,76 tys. zł), Przemyślu (98,86 tys. zł), Tarnobrzegu (102,13 tys. zł) oraz w powiecie leskim (102,69 tys. zł).

- Powiaty z dobrze rozwiniętym sektorem usług (jak na warunki województwa podkarpackiego) w badanym okresie czasu charakteryzowały się wysokimi wartościami analizowanej zmiennej makroekonomicznej. W skład tej grupy wchodziły powiaty: ropczycko-sędziszowski (112,61 tys. zł), Krosno (113,02 tys. zł), dębicki (115,03 tys. zł), sanocki (130,57 tys. zł) oraz leżajski (135,84 tys. zł).

- Najwyższe (jak na warunki województwa podkarpackiego) wartości PKB per capita występowały w powiatach mocno uprzemysłowionych, tj. Rzeszowie (136,79 tys. zł), mieleckim (137,30 tys. zł), bieszczadzkim (152,92 tys. zł), stalowowolskim ( 165,19 tys. zł) oraz tarnobrzeskim (183,85 tys. zł). Powiat bieszczadzki znalazł się w tej grupie z uwagi na duże inwestycje w sektorze turystyki po roku 2007.

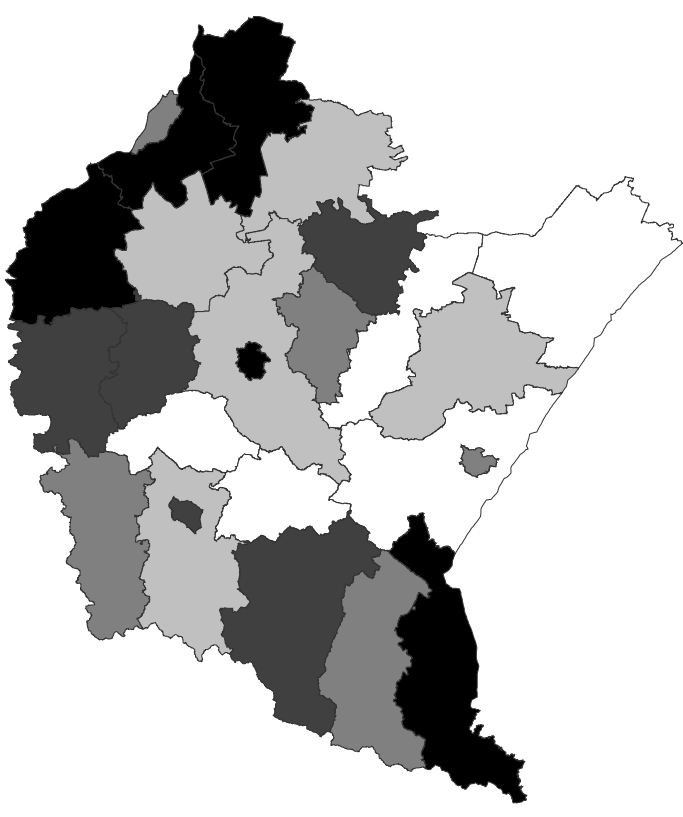

$$
38-70 \square 70-88 \square 88-112 \square 112-136
$$

$136-184$

Mapa 1. Przestrzenne zróżnicowanie PKB na mieszkańca w latach 2003-2014 w powiatach województwa podkarpackiego (w tys. zł, ceny stałe 2009)

Źródło: opracowanie własne na podstawie https://bdl.stat.gov.pl/BDL/start (dostęp: 17.11.2017 r.).

Na mapie 2 zostało zilustrowane średnie tempo wzrostu PKB w powiatach województwa podkarpackiego w latach 2003-2014. Z mapy tej możemy wyciągnąc następujące wnioski. 
- Powiaty leski (-0,049), jasielski (-0,036), krośnieński (-0,024), lubaczowski (-0,024) oraz niżański $(-0,020) \mathrm{w}$ analizowanym okresie czasu charakteryzowały się najniższymi wartościami tempa wzrostu PKB.

- Niskie wartości przeciętnych stóp wzrostu PKB w latach 2002-2014 zostały odnotowane w powiatach: brzozowskim $(-0,018)$, leżajskim $(-0,017)$, kolbuszowskim $(-0,014)$, tarnobrzeskim $(-0,013)$ oraz sanockim $(-0,006)$.

- W badanym okresie czasu powiatami o przeciętnej wartości średniej stopy wzrostu PKB były: przeworski (-0,004), Przemyśl (-0,001), Tarnobrzeg (0,003), strzyżowski $(0,004)$ jak również mielecki $(0,005)$.

- Wysokim średnim tempem wzrostu PKB charakteryzowały się powiaty: dębicki $(0,006)$, Rzeszów $(0,007)$, przemyski $(0,010)$, jarosławski $(0,011)$ oraz Krosno $(0,012)$.

- Najwyższe wartości przeciętnego tempa wzrostu PKB w województwie podkarpackim wykazywały powiaty: rzeszowski $(0,016)$, łańcucki $(0,017)$, bieszczadzki $(0,026)$, stalowowolski $(0,030)$ oraz ropczycko-sędziszowski $(0,035)$.

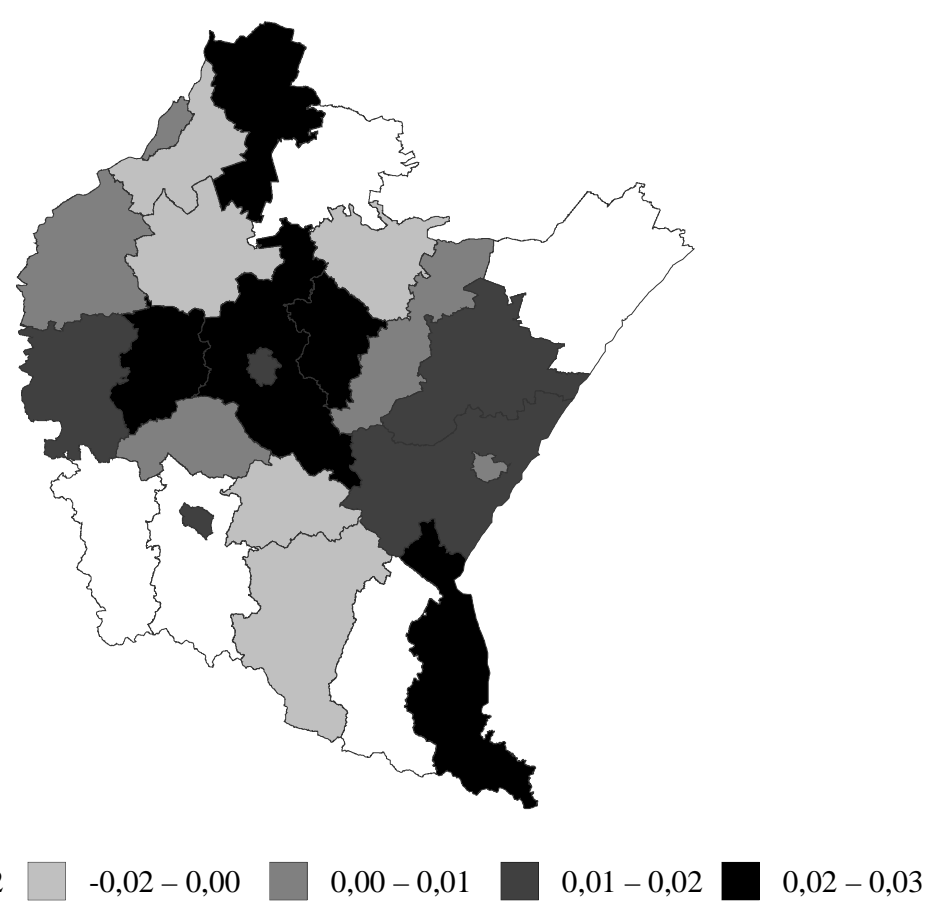

Mapa 2. Stopa wzrostu PKB per capita w powiatach województwa podkarpackiego w latach 2003-2014

Źródło: opracowanie własne na podstawie https://bdl.stat.gov.pl/BDL/start (dostęp: 17.11.2017 r.). 
Analizując drzewo skupień obrazujące podobieństwo wartości PKB w przeliczeniu na pracującego w latach 2003-2014 zilustrowane na wykresie 1 możemy dojść do następujących wniosków. Największe podobieństwo występowało pomiędzy następującymi parami powiatów: jarosławskim i rzeszowskim, jasielskim i krośnieńskim, Krosnem i ropczyckosędziszowskim, Rzeszowem i Przemyślem, lubaczowskim i strzyżowskim, leżajskim i mieleckim oraz bieszczadzkim i stalowowolskim. Ponadto z dendrogramu 1 możemy wyodrębnić następujące klastery podobieństwa. Pierwszy z nich tworzą powiaty słabo uprzemysłowione, tj. jarosławski, rzeszowski i przeworski, kolejny tworzą powiaty: jasielski, krośnieński, kolbuszowski i niżański. Trzeci klaster ma w swoim składzie powiaty o dobrze rozwiniętym przemyśle tj. dębicki, Krosno oraz ropczycko-sędziszowski. Kolejny klaster tworzą powiaty: lubaczowski, strzyżowski i przemyski, w skład ostatniego klastera wchodzą następujące powiaty: leżajski, mielecki oraz sanocki.

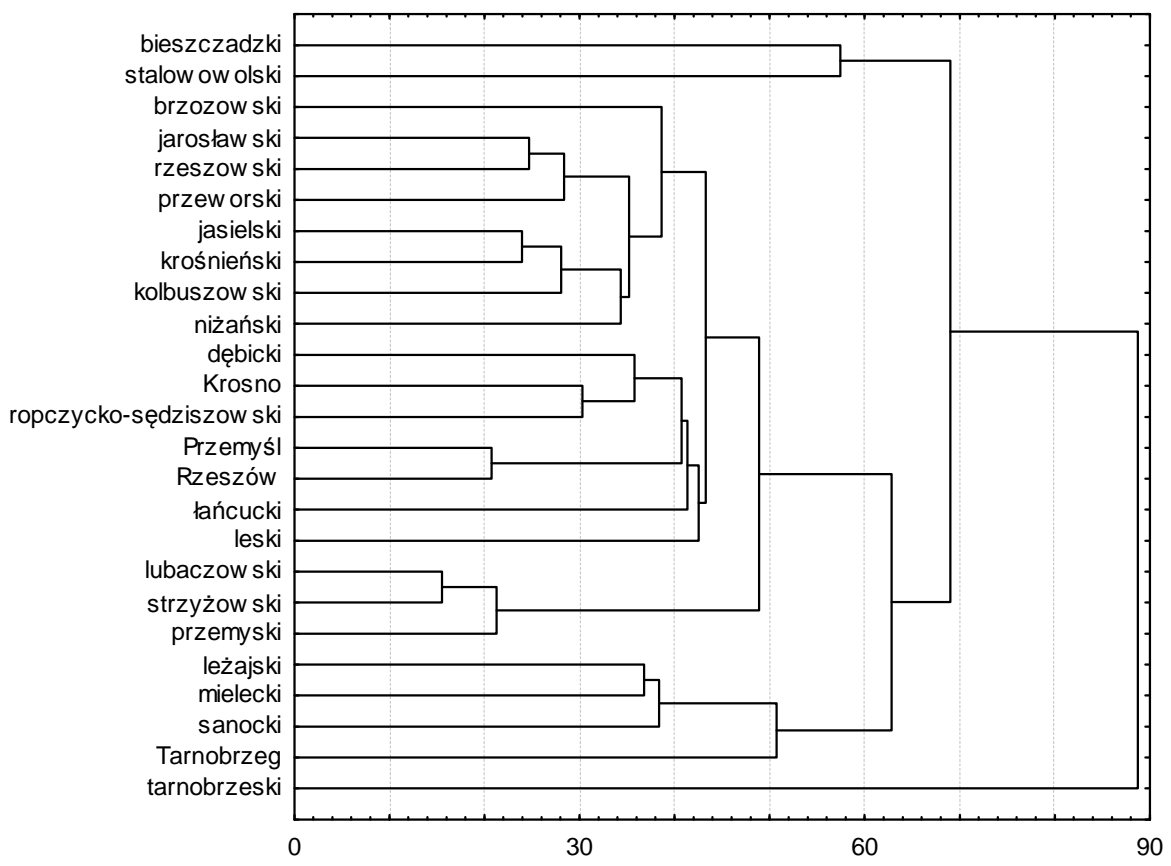

Wykres 1. Dendrogram podobieństwa powiatów województwa podkarpackiego ze względu na PKB na pracującego (lata 2003-2014, odległość euklidesowa)

Źródło: opracowanie własne na podstawie https://bdl.stat.gov.pl/BDL/start (dostęp: 17.11.2017 r.). 


\section{OSZACOWANIE ŁĄCZNEJ PRODUKTYWNOŚCI CZYNNIKÓW PRODUKCJI W POWIATACH WOJEWÓDZTWA PODKARPACKIEGO}

Aby oszacować łączną produktywność czynników produkcji można się posłużyć potęgową funkcją produkcji typu Cobba-Douglas'a ${ }^{12}$. W opracowaniu przyjęto dwuczynnikową funkcją produkcji daną wzorem:

$$
Y_{i t}=A_{0} e^{g t} K_{i t}^{\alpha} L_{i t}^{1-\alpha}
$$

przy czym:

$Y_{i t}$ to wielkość produktu w powiecie $i($ dla $i=1,2, \ldots 25)$ w roku $t($ dla $t=2003,2004, \ldots$ 2014),

$K_{i t}$ to wartość brutto środków trwałych w $i$-tym powiecie w roku $t$

$L_{i t}$ jest liczbą pracujących na $i$-tym powiatowym rynku pracy w roku $t$,

$A_{0}>0$ jest łączną produktywnością czynników produkcji dla okresu $t=0$,

$g>0$ jest to stopa postępu technicznego, która nie wpływa na poziom technicznej stopy substytucji (Technical rate of substitution) między nakładami czynników produkcji.

Ponadto parametry $\alpha \in(0 ; 1)$ oraz $(1-\alpha) \in(0 ; 1)$ są to elastyczności funkcji produkcji względem (odpowiednio) nakładów kapitału oraz pracy.

Z funkcją produkcji (2) można przejść do tzw. funkcji produkcji w postaci intensywnej dzieląc równanie (2) obustronnie przez liczbę pracujących $L_{i t}>0$, zatem ${ }^{13}$ :

$$
y_{i t}=A_{0} e^{g t} k_{i t}^{\alpha}
$$

przy czym:

$y_{i t}=Y_{i t} / L_{i t}$ oznacza wydajność pracy, zaś $k_{i t}=K_{i t} / L_{i t}$ jest technicznym uzbrojeniem pracy.

Ponadto logarytmując stronami powyższe równanie otrzymujemy:

$$
\ln \left(y_{i t}\right)=\ln \left(A_{0}\right)+g t+\alpha \ln \left(k_{i t}\right)
$$

Z równania (4) otrzymujemy:

$$
\ln \left(\frac{y_{i t}}{k_{i t}}\right)^{\alpha}=\ln \left(A_{0}\right)+g t .
$$

Zatem wyrażenie ln $\left(A_{0}\right)+g t$ jest logarytmem z łącznej produkcyjności czynników produkcji.

Wynika stąd, że estymacja parametrów równania (4) pozwoli wyznaczyć wartość parametru $\alpha$, za pomocą której można wyznaczyć wartość łącznej produktywności czynników produkcji jako:

${ }^{12}$ C.W. Cobb, P.H. Douglas, A Theory of Production, “American Economic Review” 18(1), 1928.

${ }_{13}$ T. Tokarski, Przestrzenne zróżnicowanie Łacznej produkcyjności czynników produkcji w Polsce, „Gospodarka Narodowa” nr 3/2010, 2010, s. 23-38. 


$$
T F P_{i t}=\frac{y_{i t}}{k_{i t}^{\alpha}}
$$

Ponadto równanie (4) rozszerzono o efekt dywersyfikacji stałej aby uchwycić przestrzenną heterogeniczność TFP $\mathrm{w}$ powiatach województwa podkarpackiego ${ }^{14}$. Zatem równanie (4) rozszerzono do następującego równania:

$$
\ln \left(y_{i t}\right)=\ln \left(A_{0}\right)+\sum_{j=1}^{n} \varphi_{j} d_{j}+g t+\alpha \ln \left(k_{i t}\right)
$$

przy czym $\ln \left(A_{0}\right)$ jest stałą dla powiatu bazowego,

$\varphi_{j}$ jest korekta na stałą dla $j$-tego powiatu niebazowego,

$d_{j}$ to zmienne zero-jedynkowe dla poszczególnych powiatów niebazowych.

Równanie (5) oraz (6) zakłada również stałą elastyczność wydajności pracy względem technicznego uzbrojenia pracy we wszystkich powiatach województwa podkarpackiego, co wydaje się być mało realistyczne. Parametr określający elastyczność wydajności pracy względem technicznego uzbrojenia pracy jest uśredniony dla wszystkich powiatów województwa podkarpackiego, prowadzić to będzie do spłaszczenia przestrzennego zróżnicowania TFP w powiatach omawianego województwa. Sytuacja ta uwypukla się szczególnie w przypadku powiatów grodzkich, w których notowane są zdecydowanie wyższe poziomy technicznego uzbrojenia pracy. W konsekwencji prowadziłoby to do niedoszacowania TFP w powiatach grodzkich. Z tego powodu spośród powiatów województwa podkarpackiego wyodrębniono cztery powiaty grodzkie: Krosno, Przemyśl, Rzeszów oraz Tarnobrzeg i dla tych powiatów oszacowano ową elastyczność. Zatem w opracowaniu oszacowano elastyczność wydajności pracy względem technicznego uzbrojenia pracy w powiatach grodzkich oraz powiatach ziemskich województwa podkarpackiego.

Parametry równań (4) oraz (6) oszacowano w wyżej wymienionych grupach powiatów, zaś wyniki przedstawione zostały w tabeli 1 .

Z oszacowań równań (4) oraz (6) przedstawionych w tabeli 1 wynika, iż parametr opisujący elastyczność wydajności pracy względem technicznego uzbrojenia pracy były istotnie zróżnicowane w rozważanych grupach powiatów. Dowodzi to tezy postawionej w poprzedniej części artykułu mówiącej o tym, że elastyczność wydajności pracy względem technicznego uzbrojenia pracy istotnie różniła się między grupami powiatów ziemskich oraz grodzkich. Ponadto wyższym poziomem owej elastyczności charakteryzowały się powiaty ziemskie $($ ok. 0,49$)$ niż powiaty grodzkie (ok. $0,24-0,28)$. Ponadto oszacowana stopa postępu technicznego była niższa w powiatach grodzkich i wynosiła, w zależności od estymowanego równania, między $0,83 \%$ a $1,4 \%$. Zaś stopy postępu technicznego w powiatach ziemskich województwa podkarpackiego kształtowały się na podobnym poziomie w obu analizowanych równaniach i wynosiły ok. 1,4\%. Wartości uzyskanych skorygowanych współczynników determinacji w estymowanych równaniach bez uzmienniania stałej wynosiły (odpowiednio) 55\% dla powiatów ziemskich oraz 43\% dla grodzkich. Natomiast prowadzenie efektów indywidualnych znacząco poniosło wartości skorygowanych współczyn-

${ }^{14}$ R.S. Pindyck, D.L. Rubinfeld, Econometric Models and Economic Forecast, McGraw-Hills, New York 1991, s. 223-226. 
ników determinacji do poziomu (odpowiednio) 92\% wśród powiatów ziemskich i 83\% dla powiatów grodzkich.

Tabela 1. Oszacowania GMM parametrów równań (4) oraz (6)

\begin{tabular}{|c|c|c|c|c|}
\hline \multirow{2}{*}{$\begin{array}{c}\text { Zmienna } \\
\text { objaśniająca }\end{array}$} & \multicolumn{2}{|c|}{ Równanie (4) } & \multicolumn{2}{c|}{ Równanie (6) } \\
\cline { 2 - 5 } & ziemskie & grodzkie & ziemskie & grodzkie \\
\hline \multirow{2}{*}{ Stała } & $-24,4901$ & $-15,3298$ & $-26,8924$ & $-25,8928$ \\
& $(0,0000)$ & $(0,0000)$ & $(0,0000)$ & $(0,0000)$ \\
\hline \multirow{2}{*}{$t$} & 0,0141 & 0,00829 & 0,0151 & 0,0143 \\
& $(0,0000)$ & $(0,0000)$ & $(0,0000)$ & $(0,0000)$ \\
\hline \multirow{2}{*}{$\ln \left(k_{i t}\right)$} & 0,4982 & 0,2802 & 0,4923 & 0,2383 \\
& $(0,0001)$ & $(0,0000)$ & $(0,0000)$ & $(0,0000)$ \\
\hline$R^{2}$ & 0,58 & 0,48 & 0,96 & 0,87 \\
Skor. $R^{2}$ & 0,55 & 0,43 & 0,92 & 0,83 \\
\hline
\end{tabular}

W nawiasach wartości $p$-value natomiast za instrumenty przyjęto stałą oraz $\ln \left(K_{i t-1}\right)$. Źródło: obliczenia własne na podstawie https://bdl.stat.gov.pl/BDL/start (dostęp: 17.11.2017 r.).

\section{ZRÓŻNICOWANIE ŁACZNEJ PRODUKTYWNOŚCI CZYNNIKÓW PRODUKCJI W POWIATACH WOJEWÓDZTWA PODKARPACKIEGO}

$\mathrm{Z}$ danych zawartych na mapie 3 przedstawiającej przestrzenne zróżnicowanie kształtowania się TFP w latach 2003-2014 w powiatach województwa podkarpackiego możemy wyciągnąć następujące wnioski:

- Zdecydowanie najniższe wartości TFP (nieprzekraczające 40) w analizowanym okresie czasu zostały odnotowane w powiatach słabo uprzemysłowionych: przemyskim $(14,28)$, strzyżowskim $(22,47)$, brzozowskim $(29,53)$, lubaczowskim $(33,24)$ i niżańskim $(39,26)$.

- Grupę o niskich wartościach łącznej produktywności czynników produkcji tworzyły powiaty: przeworski $(47,31)$, kolbuszowski $(49,24)$, leski $(65,16)$, krośnieński $(67,03)$ oraz rzeszowski $(68,79)$.

- Przeciętne wartości TFP w grupie powiatów województwa podkarpackiego tworzyły powiaty: łańcucki $(74,31)$, ropczycko-sędziszowski $(79,91)$, bieszczadzki $(79,99)$, jarosławski $(80,52)$ oraz jasielski $(97,49)$.

- Wysokimi wartościami łącznej produktywności czynników produkcji charakteryzowały się trzy powiaty grodzkie jak również powiaty dobrze uprzemysłowione. Grupę tę tworzyły powiaty: Przemyśl $(123,31)$, dębicki $(124,73)$, Krosno $(131,65)$, tarnobrzeski $(135,73)$ jak również Rzeszów $(148,66)$.

- W powiatach: Tarnobrzeg $(150,52)$, leżajskim $(155,32)$, stalowowolskim $(199,51)$, mieleckim $(205,48)$ oraz sanockim $(276,53)$ występowały najwyższe wartości TFP w analizowanym okresie. 


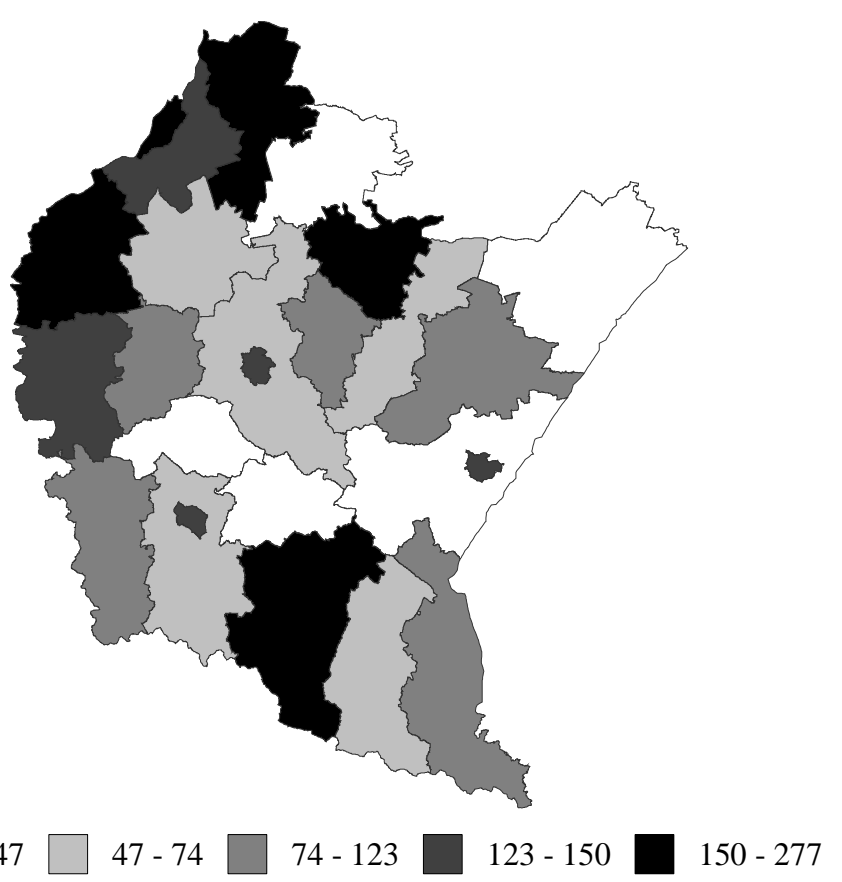

Mapa 3. Przestrzenne zróżnicowanie TFP w latach 2003-2014 w powiatach województwa podkarpackiego

Źródło: obliczenia własne na podstawie https://bdl.stat.gov.pl/BDL/start (dostęp: 17.11.2017 r.).

W powiatach województwa podkarpackiego występował zarówno ujemny, jak i dodatni poziom zmian łącznej produktywności czynnik produkcji. Analizując dane zawarte na mapie 4 przedstawiającej przestrzenne zróżnicowanie tempo wzrostu łącznej produktywności czynników produkcji w latach 2003-2014, możemy dojść do następujących wniosków:

- Największy spadek TFP w województwie podkarpackim odnotowano w powiatach: krośnieńskim (-0,039), jasielskim $(-0,035)$, leskim $(-0,028)$, przeworskim $(-0,026)$ oraz w Przemyślu (-0,022).

- W grupie powiatów o wysokim spadku łącznej produktywności czynników produkcji znalazły się powiaty: jarosławski $(-0,021)$, Tarnobrzeg $(-0,020)$, leżajski $(-0,014)$, mielecki $(-0,012)$ oraz stalowowolski $(-0,009)$.

- Przeciętne wartości tempa wzrostu TFP zostały przypisane do powiatów: sanockiego $(-0,001)$, brzozowskiego $(0,002)$, strzyżowskiego $(0,002)$, kolbuszowskiego $(0,005)$, łańcuckiego $(0,005)$.

- Wysoki wzrost TFP w latach 2003-2014 został odnotowany w powiatach: lubaczowskim $(0,006)$, przemyskim $(0,006)$, Rzeszowie $(0,010)$, dębickim $(0,010)$ oraz niżańskim $(0,012)$. 
- Największy wzrost łącznej produktywności czynników produkcji w badanym okresie czasu został odnotowany w powiatach: Krosno $(0,021)$, tarnobrzeskim $(0,030)$, ropczycko-sędziszowskim $(0,035)$, rzeszowskim $(0,050)$ oraz bieszczadzkim $(0,052)$.

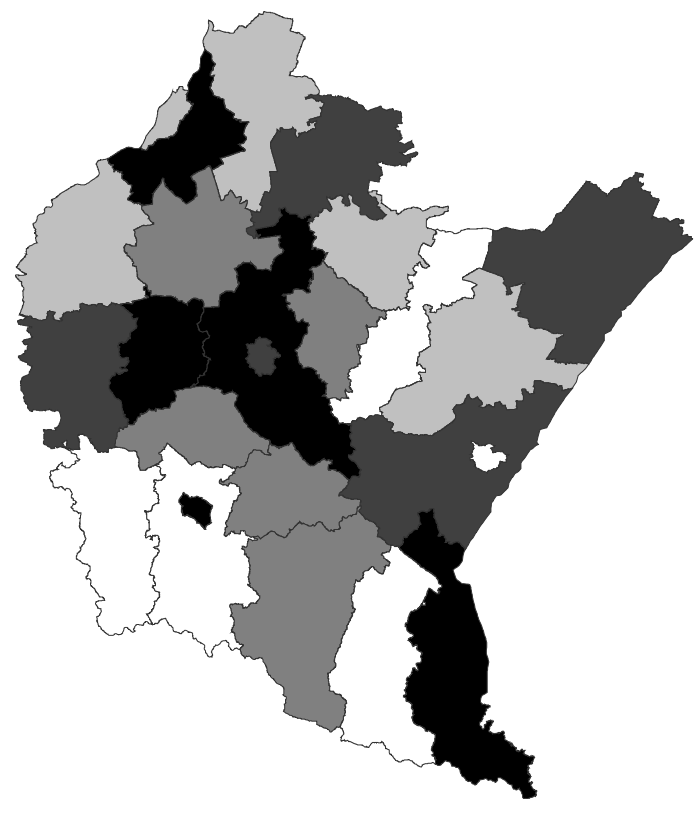

$-0,04--0,02$ $-0,02-0,00$ $0,00-0,01$ $0,01-0,02$

$0,02-0,05$

Mapa 4. Przestrzenne zróżnicowanie tempa wzrostu TFP w latach 2003-2014 w powiatach województwa podkarpackiego

Źródło: obliczenia własne na podstawie https://bdl.stat.gov.pl/BDL/start (dostęp: 17.11.2017 r.).

Z analizy drzewa skupień zaprezentowanego na wykresie 2 możemy wyodrębnić 6 par powiatów podobnych do siebie pod względem łącznej produktywności czynników produkcji. Podobne powiaty to: brzozowski i kolbuszowski, mielecki i przeworski, rzeszowski i strzyżowski, Rzeszów i sanocki, ropczycko-sędziszowski i stalowowolski oraz bieszczadzki i tarnobrzeski. Ponadto drzewo to przedstawia nam 4 klastery podobieństwa. Pierwszy z nich zawiera następujące powiaty: brzozowski, kolbuszowski i krośnieński, kolejny ma w swoim składzie powiaty: dębicki, mielecki, przeworski, łańcucki i Krosno. W skład następnego klastera podobieństwa wchodzą powiaty: jasielski, Przemyśl, rzeszowski, strzyżowski, Rzeszów oraz sanocki. Ostatni klaster podobieństwa który możemy wyodrębnić z wykresu 2 zawiera powiaty: ropczycko-sędziszowski, Tarnobrzeg i stalowowolski. 


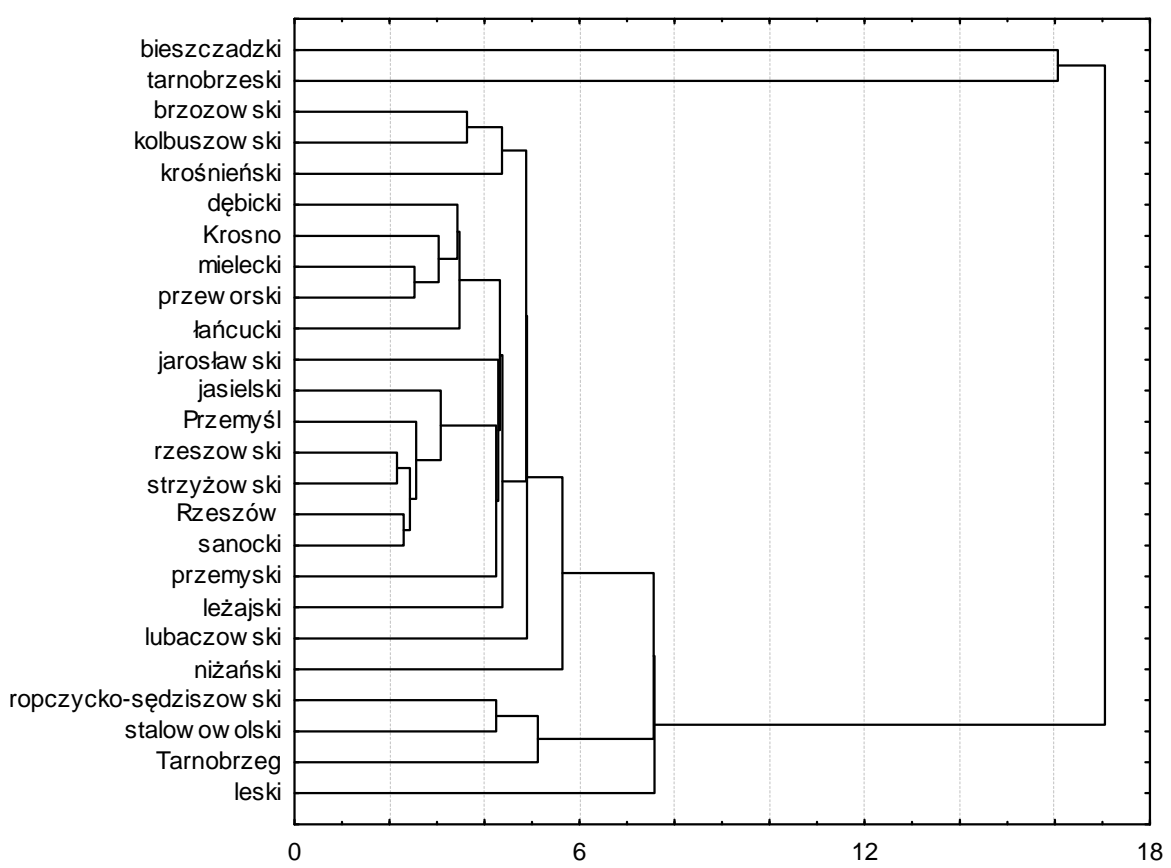

Wykres 2. Dendrogram podobieństwa powiatów województwa podkarpackiego ze względu na wartości łącznej produktywności czynników produkcji (lata 2003-2014, odległość euklidesowa)

Źródło: obliczenia własne na podstawie https://bdl.stat.gov.pl/BDL/start (dostęp: 17.11.2017 r.).

\section{PODSUMOWANIE}

Z przeprowadzonych w opracowaniu rozważań można wysnuć następujące wnioski:

- Wyższym poziomem elastyczności wydajności pracy względem technicznego uzbrojenia pracy charakteryzowały się powiaty ziemskie 0,49 , zaś powiaty grodzkie cechowały się poziomem owej elastyczności wynoszącym 0,24.

- Oszacowana stopa postępu technicznego w powiatach ziemskich województwa podkarpackiego wynosiła 1,5\%, zaś dla powiatów grodzkich omawianego województwa stopa postępu technicznego kształtowała się na poziomie ok. 1,4\%.

- Ponadto $\mathrm{z}$ analiz przestrzennego zróżnicowania TFP $\mathrm{w}$ powiatach województwa podkarpackiego najniższe, wartości TFP w badanym przedziale czasu osiągnęły powiaty przemyski, strzyżowski, brzozowski, lubaczowski oraz niżański.

- Powiaty grodzkie charakteryzowały się najwyższymi wartościami TFP w województwie podkarpackim. Ponadto do grupy o najwyższych wartościach TFP należały również powiaty Tarnobrzeg, leżajski, stalowowolski, mielecki oraz sanocki. 


\section{LITERATURA}

1. Bolińska M., Przestrzenne zróżnicowanie rozwoju ekonomicznego powiatów województwa podkarpackiego, „Przegląd Nauk Ekonomicznych”, nr 25, 2017.

2. Bolińska M., Wptyw Specjalnych Stref Ekonomicznych na przestrzenne zróżnicowanie stóp bezrobocia rejestrowanego w powiatach województwa podkarpackiego, Przegląd Nauk Ekonomicznych, nr 25, 2017.

3. Ciołek D. Brodzicki T., Determinanty całkowitej produktywności polskich powiatów. Wpływ kapitału terytorialnego, ,Working Paper” 1, Instytut Rozwoju, 2015.

4. Ciołek D., Brodzicki T., Determinanty produktywności polskich powiatów, „Bank i Kredyt” 47(5), 2016, s. 463-494.

5. Cobb C.W., Douglas P.H., A Theory of Production, “American Economic Review” 18(1), 1928.

6. Dykas P., Misiak T., Przestrzenne zróżnicowanie TFP w grupach powiatów, referat wygłoszony na konferencji naukowej „Wzrost Gospodarczy - Rynek Pracy - Innowacyjność Gospodarki” organizowanej przez Uniwersytet Łódzki, Łódź czerwiec 2017.

7. Dykas P., Misiak T., Determinanty podstawowych zmiennych rynku pracy $w$ polskich powiatach w latach 2002-2011, „Gospodarka Narodowa”, 6/2014.

8. Dykas P., Szewczyk M., Zróżnicowanie rozwoju ekonomicznego powiatów Polski Wschodniej [w:] Zintegrowane podejście do spójności - rola statystyki publicznej, red. A. Piotrowska-Piątek, Miscellanea Oeconomicae, R. 19, nr 4/2015, t. I.

9. Easterly W., Levine R., What Have we learned from a decade of empirical research on growth? It's not factor accumulation: stylized facts and growth model, "World Bank Economic Review", 15(2), 2001.

10. Helpman E., The mystery of economic growth, Harvard University Press, 2008.

11. Pindyck R.S., Rubinfeld D.L., Econometric Models and Economic Forecast, McGrawHills, New York, 1991.

12. Tokarski T., Oszacowanie regionalnych funkcji produkcji, „Wiadomości Statystyczne”, nr 10, 2008.

13. Tokarski T., Przestrzenne zróżnicowanie Łącznej produkcyjności czynników produkcji w Polsce, ,Gospodarka Narodowa” nr 3/2010, 2010.

14. Tokarski T., Zróżnicowanie podstawowych zmiennych makroekonomicznych $w$ powiatach [w:] Statystyczna analiza przestrzennego zróżnicowania rozwoju ekonomicznego i społecznego Polski, red. M. Trojak, T. Tokarski, Kraków 2013.

\section{NETOGRAFIA}

1. https://bdl.stat.gov.pl/BDL/start

\section{DIFFERENTIATION OF TOTAL PRODUCTIVITY OF PRODUCTION FACTORS IN DISTRICTS PODKARPACKIE VOIVODSHIP}

The article presents an analysis of the diversification of the total factor productivity in districts of the Podkarpackie Voivodeship. The aim of the article is to estimate both the level and dynamics of the total factor productivity in this voivodship. The analysis period included the years 2003-2014. In order to determine the total factor productivity, the author disaggregated GDP from the level of the voivodeship to the districts level. The total factor productivity was 
calculated based on the previously disaggregated value of GDP at the districts level and on the neoclassical, power, Cobb-Douglas production function. The parameters of the production function were estimated based on the generalized method of moments. From conducted analyses we can draw the following conclusions. The highest values of disaggregated GDP per capita were recorded in districts: Rzeszowie, mieleckim, bieszczadzkim, stalowowolskim and tarnobrzeskim. The lowest, as for the conditions of the Podkarpackie Voivodeship, the value of disaggregated GDP per capita occurred in districts przemyskim, lubaczowskim, strzyżowskim, brzozowskim and przeworskim. The highest level of total factor productivity was characteristic for town districts (Rzeszów, Krosno and Tarnobrzeg) and districts with well-developed service and industrial sectors. Farther, in the years 2003-2014 the lowest values of the total factor productivity were recorded mainly in the districts of the southern and south-eastern part of the Podkarpackie Voivodeship, to which districts count the districts przemyski, strzyżowski, brzozowski, lubaczowski and niżański.

Keywords: TFP, technical progress rate, flexibility of work efficiency in relation to technical equipment of work, spatial diversity of TFP.

DOI: 10.7862/rz.2018.hss.20

Przestano do redakcji: kwiecień $2018 \mathrm{r}$.

Przyjęto do druku: czerwiec 2018 r. 
